\title{
The Role Played by Institutional Support in the Commitment, Job Satisfaction and Employee Performance of Teachers in Gauteng Province of South Africa: A Social Exchange Perspective
}

\author{
Elizabeth Chinomona \\ Vaal University of Technology, South Africa \\ Faculty of Management Sciences, Vanderbijlpark, 1900, South Africa \\ Email: chakubvae@hotmail.com

\section{Kholeka Constance Moloi} \\ Faculty of Human Sciences \\ Vanderbijlpark, 1900, South Africa \\ Email: conniem@vut.ac.za
}

\section{Doi:10.5901/mjss.2014.v5n2p303}

\begin{abstract}
This quantitative study investigates the role played by institutional support in the commitment, job satisfaction and job performance of teachers in the Gauteng province of South Africa. Drawing from a social exchange perspective, the researchers argue that institutional support has a positive influence on institutional commitment, job satisfaction and employee performance. However, there are relatively few studies that seek to investigate the influence of institutional support on teachers' level of commitment, job satisfaction and workplace performance, particularly in the developing countries of Southern Africa. Three research hypotheses are posited and data collected from a sample of 150 teachers in colleges and universities in the Gauteng province of South Africa are used to test the hypotheses empirically. The results of this study show that institutional support positively influences teachers' job commitment, job satisfaction and job performance. Managerial implications of the findings are discussed and limitations and future research directions are indicated.
\end{abstract}

Keywords: Institutional support, commitment, teacher job satisfaction, job performance.

\section{Introduction}

The spate of literature on institutional support (organisational support) has proved beyond reasonable doubt that this is an important phenomenon in organisational behaviour because it leads to positive results in the workplace (Ferris, Brown \& Heller, 2009; Zagenczyk, Scott, Gibney, Murrell \& Thatcher, 2010; Baranik, Rolling \& Eby, 2010; Arshadi 2011). Like the roots of a tree that support the whole tree, institutional support caters for all the employees in the organisation in terms of resources and personal needs. Many authors have tried to define institutional support in various ways. Institutional support refers to 'the extent to which the organisation values their contributions and cares about their wellbeing' (Eisenberrger, Huntington, Hutchison \& Sowa, 1986). According to Bilgin and Demirer (2012), institutional support is about rewarding and meeting the socio-emotional needs of employees. The current study defines employee job satisfaction as a positive affective state resulting from the appraisal of all aspects of a job by the employee. Such employee job satisfaction can be derived from economic outcomes or social interactions at the workplace. Job satisfaction, according to Abdullah, Bilau, Eneghum, Ajogbe and Alli (2011), implies the positive emotional state of an employee as a result of pleasurable job experiences. The sources of job satisfaction are appreciation, communication, co-worker relationships, fringe benefits, job conditions, the nature of the work itself, the nature of the organisation, organisational policies and procedures, pay, growth, promotion opportunities, recognition, security and supervision (Lu, Barriball, Zhang \& While, 2011).

Consistent with social exchange theory (Blau, 1964) and the reciprocity norm (Gouldner, 1960), institutional support obligates employees who feel supported to reciprocate by expressing greater affective organisational commitment, performing citizenship behaviours and exhibiting lower levels of withdrawal (Rhoades \& Eisenberger, 2002). As a result, organisations that foster support for employees are thought to have a competitive advantage over 
organisations that do not (Pfeffer, 2005; Casper, Harris, Taylor-Bianco \& Wayne, 2011 \& Zacher \& Winter, 2011). The review of the literature revealed that, despite the recognition that institutional support is a catalyst for the employee outcomes of job satisfaction, commitment and performance, research on the relationship between these constructs in the education sector is scarce, if not non-existent. As Malhotra and Mukhejee (2004) have observed, most of the research examining these relationships has been conducted in private organisations such as hotels, banks and insurance companies (Way et al., 2010; Abdullah, Bilau, Enegbuma, Ajagbe \& Ali, 2011; Chiang \& Hsieh, 2012).

Furthermore, most of these studies were carried out in American, European and Asian countries (Noblet \& Rodwell, 2009; Bowling, 2010; Miao, 2011) and only a few in Africa (Abdullah et al., 2011). Research by Rhoades \& Eisenberger (2002) indicates that when employees perceive that they are supported, they tend to be satisfied with their jobs, exhibit high job performance, are committed to and identify with the organisation and help the organisation succeed through citizenship behaviours and decreased withdrawal behaviours. In this regard, Rhoades and Eisenberger (2002) found that institutional support positively impacts on job satisfaction, while Miao (2011) also reports a positive correlation between institutional support and job performance. In addition, research reported in the literature has also shown conclusively that there is a positive relationship between job satisfaction and job performance (Bowling, 2010; Way, Sturman \& Raab, 2010). According to Bowling (2010), employees who are satisfied with their jobs tend to work hard, do extra work and become committed to the organisation.

\subsection{Problem Statement}

It may be misleading to assume a priori that the results found in these developed countries are applicable to developing countries and emerging economies like South Africa. The lack of a comprehensive model showing relationships between institutional support, job commitment, job satisfaction and performance in the colleges and universities is a major shortcoming. This undermines the development of interventions to retain and motivate teachers in order to improve the service which they provide. In view of these challenges, the current study seeks to investigate the influence of institutional support on teacher job satisfaction, job commitment and performance in South African colleges and universities in the Gauteng province in South Africa. The results will provide insights to education leaders who are Heads of Departments (HODs), Deans and Vice Chancellor and their deputies on how to support teachers in order to improve the quality of teaching. The study would also make an important contribution by advancing the body of knowledge on institutional support, job satisfaction, job commitment and performance in the context of institutions of higher learning in South Africa.

\section{Theoretical Framework}

The theoretical framework that undergirds this study is a social exchange theory (SET). The fundamental premise of SET is that parties involved in exchanges voluntarily provide benefits, invoking obligation from the other party to reciprocate and provide some benefit in return (Yoon \& Lawler, 2005). The reciprocated benefits can be in the form of economic rewards or social benefits (Yoon \& Suh, 2003). Thus, social exchange is defined as voluntary actions of individuals that are motivated by the returns they are expected to bring and typically do, in fact, bring from others (Blau, 1964). The underlying principle of social exchange theory demonstrates that reciprocated benefactions create social bonds among exchange actors (Kacmar, Bachrach, Harris \& Noble, 2012). This is because social exchange builds up feelings of personal obligation, gratitude and trust among partners, all of which lay a foundation of social solidarity and micro social order, even without binding contracts (Thye, Yoon \& Lawler, 2002; Yoon \& Suh, 2003).

The term 'social exchange' is also generally applied to interactions in which giving and receiving material or intangible resources is at least partially predicated on the expectations of return or 'reciprocity' (Homans 1958; Blau 1964). The representative scholars developing the schools of the theory include Homans (1958): exchange behaviourism; Blau (1964; 1994): exchange structuralism; Thibaut and Kelley (1959): exchange outcome matrix; and Emerson (1972): exchange network. They have made significant contributions to the theory by developing conceptions of social structure in their attempts to provide explanatory frameworks that encompass both human behaviour and institutional persistence and change management. Social exchange theory explains the exchange relations between two actors who exchange resources with each other (Rubin, Bommer \& Bachrach, 2010; Luo, 2002). In the context of this study, these actors are teachers and the employer (including direct supervisors). In light of this, each exchange actor provides what the other wants and thus both are able to can gain access to complementary resources (that is, teaching, learning, research activities and remuneration for services). Exchange actors are motivated to seek self-interest, increase 
rewards and decrease costs. These outcomes are compared with other exchange alternatives and, consequently, positive outcomes may increase trust, cooperation, satisfaction and commitment, leading over time to the development of norms that govern the relationship and organisational citizenship behaviours (OCBs) (Zellars, Tepper \& Duffy, 2002; Flynn, 2003; Zellars \& Tepper, 2003; Flynn, 2005). In this regard, Rubin, Bommer \& Bachrach (2010:401) contend that an individual's intention to continue to make a commitment to a relationship depends on his satisfaction and the comparison level of alternatives. According to Cropanzano \& Mitchell (2005), the exchange party assesses the social and economic outcomes (rewards obtained and costs incurred) from a given exchange relationship in comparison with expectations based on present and past experience with similar relationships.

The underlying principle of social exchange theory demonstrates that reciprocated benefactions create social bonds among exchange actors and lead to greater OCBs (Kacmar, Bachrach, Harris \& Noble, 2012; Yen \& Teng, 2012). Given the uncertainty inherent in social exchange, exchange partners may encounter information deficiency, and, according to Blau (1964) and Molm (2000), information is essential for the development of trust and commitment. These scholars indicated that trust can reduce uncertainty and risk in exchange relationships. Since an exchange partner repeatedly exchanges with another, his act becomes more trustworthy and his behaviour is more predictable. The social exchange theory is helpful in framing the exchange relationship between institutional management and teachers in the context of this study. In the next section, the researchers discuss institutional support to expose the context within which commitment, job satisfaction and employee performance of teachers obtain.

\subsection{Institutional Support}

According to Rhoades and Eisenberger (2002), employees perceive that the institution supports them if resources are provided voluntarily rather than after pressure from trade unions and government regulations on health and safety. Similarly, Chiang and Hsieh (2012) assert that perceived institutional support is the belief that the employer cares about the needs of employees. It involves mentorship activities such as employee counselling, providing workshops for employees, developing the employees in terms of academic advancement, making sure the teachers have adequate resources in the classroom, employee protection, coaching employees, ensuring friendship among employees and role modelling (Baranik, Roling \& Eby, 2010). However, research by Cloete (2011:1) shows that, owing to difficulties with policy issues of equity, efficiency, democratic participation, development and massification of higher education in South Africa against declining resources, teachers and other employees tend to feel that their needs are not sufficiently catered for. This has recently resulted in numerous strikes by teachers at various institutions of higher learning in the country. Given that higher education is now acknowledged as a major driver of the information-knowledge system (Cloete, 2011:1), these institutions are urged to support teachers and other employees by creating career opportunities through various professional development initiatives and providing time for such activities (Amin, 2013). As Rhoades and Eisenberger (2002) and Bilgin and Demirer (2012) showed, the components of perceived institutional support include training, autonomy, job security, job safety, recognition, pay, promotion, fairness, and work conditions.

\subsection{Teachers' job satisfaction}

In the field of organisational behaviour studies and human resources practice, there is increasing recognition of the fundamental significance of the concept of job satisfaction (Lu, Barriball, Zhang \& While, 2012; Georgellis, Lange \& Tabvuma, 2012). For instance, Yoon and Suh (2003), Yeh (2013) and Phelps and Zoega (2013) showed that satisfied employees are more likely to work harder and provide better services via organisational citizenship behaviours. In most cases, job satisfaction results when management supports and rewards teachers, although other factors like lack of promotion, work overload, long hours and large classrooms can result in dissatisfaction among teachers in the Gauteng province. Also, when policies are perceived to be fair, the employee will be satisfied. Unfortunately, educational policies are determined by the government. For example, policies on the massification of higher education have now contributed to the current crisis of low participation, as well as the inconsistent application of equity and efficiency policy assumptions (Cloete, 2011:1). However, evidence mounting from previous studies indicates that job satisfaction is the most robust antecedent of employee commitment, service quality delivery, organisational citizenship behaviours and low employee turnover intention, among others (Silvestro \& Cross, 2000; Lu et al., 2012; Yeh, 2013).

Markovits, Davis, Fay and Dick (2010) identified two dimensions of job satisfaction, namely extrinsic satisfaction and intrinsic satisfaction. While extrinsic satisfaction concerns satisfaction with pay, physical conditions and organisational policies and procedures, intrinsic satisfaction includes aspects such as creativity, achievement and 
accomplishment. According to Abdullah et al. (2011), it is crucial for organisations to make sure that employees are satisfied with their jobs because this results in positive outcomes such as high productivity and increased life gratification. Rhoades and Eisenberger (2002) and Georgellis et al. (2012) maintain that meeting the socio-emotional needs of employees leads to positive mood, feelings of competence and worth, increased interest in the job and high morale, thereby enhancing job satisfaction. This indicates that organisations can achieve competitive advantages if they create conditions that promote job satisfaction, because employees become committed to their jobs and, as a result, are likely to engage in citizenship behaviours (OCBs).

\subsection{Teacher job performance}

Damanpour and Evan (1984) proposed a systems approach, defining job performance as the ability of an organisation to cope with all four systematic processes - inputs, outputs, transformations and feedback - relative to its goal-seeking behaviour. A high-performing organisation would accomplish its primary tasks efficiently and would carry out its organisation-maintaining and organisation-adapting functions effectively (Taghipour \& Dejban 2013; Ng \& Feldman 2013; Yozgat, Yurtkoru \& Bilginoglu 2013). According to Chiang and Hsieh (2012), job performance means fulfilling specific job requirements, meeting job performance standards and expectations, effectiveness in the job and the ability to produce quality work. Miao (2011) identified two categories of job performance: role/task and discretionary/extra role performance. The role/task performance is the performance that is prescribed by the business and which the employees are obligated to perform. On the other hand, the extra role performance is the employees' citizenship behaviour, which deals with extra roles performed by the employee to support the role/task role, and which depends on the employee's discretion. $\mathrm{Ng}$, Sorensen and Yim (2009) contend that examples of extra role performance are altruism (willingness to help colleagues), conscientiousness (willing to work extra hours), sportsmanship (not complaining about trivial issues), courtesy (involving others before taking action), and civic virtue (knowing things that affect the business). Generally, organisational performance covers a wide range of outcomes such as financial performance, market share, market growth, productivity, human resource management, customer satisfaction level, customer orientation, employee efficiency, employee turnover, absenteeism, motivation and so on. Nevertheless, in order to measure business performance, many researchers have recently adopted a market performance measure that employs an even broader conceptualisation of business performance and focuses on factors that ultimately lead to financial performance (Vorhies \& Morgan, 2005). Bearing all this in mind, the current study adopts a market performance measure epitomised by sales, growth and market share (Homburg, Hoyer \& Fassnacht, 2002; Ng et al. 2009) to measure small business performance.

\subsection{Teacher job commitment}

Organisational commitment has captured the hearts and minds of scholarly researchers for many decades (Banai, Reisel \& Probst, 2004). Practitioners have been similarly enamoured because of the desirable consequences attributed to high levels of organisational commitment, such as increased effort expenditure, higher job satisfaction, decreased absenteeism, retention and organisational citizenship behaviours (Jones \& Mcintosh, 2010; Carmon, Miller, Raile \& Roers, 2010; Nordin, 2011; Morrow, MacElroy \& Scheibe, 2012; Grawe, Daugherty \& MacElroy, 2012; Yamaguchi, 2013). In many ways, organisational commitment has been referred to as a 'mature construct' (Morrow, 2011). Organisational commitment continues to be valued by organisational leaders (Morrow, 2011) despite the fact that organisations are currently operating in an era no longer characterised by long-term employment (Carmeli, 2005).

A common definition of organisational commitment is that committed individuals believe in and accept organisational goals and values. Individuals are willing to remain with their organisations and are willing to expend considerable effort on their behalf (Mowaday, Porter \& Steers, 1979; Cater \& Zabka, 2009). Meyer and Allen (1991) provide empirical evidence that organisational commitment is a multidimensional concept that provides a comprehensive insight into the link between employees and work-related behaviour. Highly committed employees are less likely to engage in withdrawal behaviour and are more willing to accept change (Sommers, 1996, Iverson, 1996. Researchers have discovered three components involved in organisational commitment: affective or emotional commitment; continuance, calculative or instrumental commitment; and normative or moral commitment (Meyer \& Allen, 1997; Morrow et al., 2012; Jones \& McIntosh, 2010). Affective organisational commitment focuses on an employee's identification with and involvement in an organisation and emphasises the bond between the employee and the organisation (Allen \& Meyer, 1990). Organisations with employees who demonstrate strong affective commitment are more effective and employees who display high levels of AOC are more productive and less likely to quit (Cooper-Hakim \& Viswesvaran, 
2005). Normative commitment means that partners stay in the relationships because they feel they ought to (Kumar, Hibbard \& Stern, 1994; Geyskens, Steenkamp, Scheer \& Kumar, 1996; Meyer, Stanley, Herscovitch \& Topolnytsky, 2002). Employees with strong normative commitment remain in an organisation because 'they ought to' (Allen \& Meyer, 1990). Calculative commitment is the extent to which partners perceive the need to maintain a relationship because of the significant anticipated switching costs or lack of alternatives (Meyer \& Herscovitch, 2001). Calculative commitment is a negatively oriented type of motivation (Allen \& Meyer, 1997), where employees have a motivation to continue the relationship because they cannot easily replace their current organisation and because they cannot obtain the same resources and outcomes outside their current organisation (Ruyter, Moorman \& Lemmink, 2001).

\section{Conceptual Framework and Hypotheses}

Based on review of the literature, the conceptual model was developed as shown in Figure 1. Four basic constructs, which were discussed in the preceding section, make up the conceptual model. These constructs are institutional support, teacher's job satisfaction, teacher's job commitment and teacher's job performance. The relationships between the proposed constructs in the conceptual model are as follows: institutional support provides the starting point of the model, and it directly impacts on job satisfaction, job commitment and performance intention. Finally, teachers supported in terms of resources and personal growth and development are likely to be satisfied and committed and to improve their performance. The hypotheses that were developed explain the relationships among the constructs in detail.

Figure 1: Conceptual Model: Institutional support, teacher job commitment, teacher job satisfaction and teacher job performance

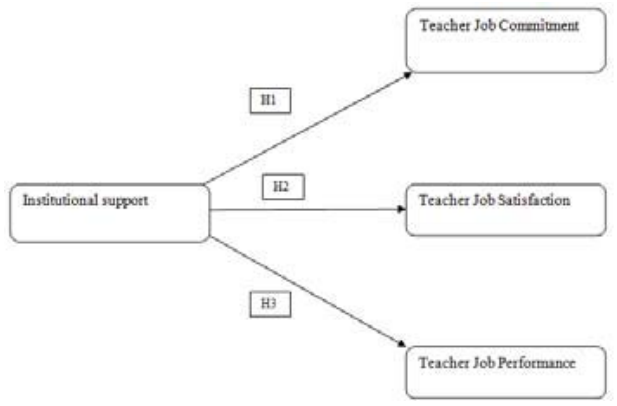

\subsection{Institutional support and teacher job commitment}

Empirical evidence in previous studies has demonstrated that the relationship between institutional support and commitment is positive. For example, the obligation to exchange caring for caring (Foa \& Foa, 1980) should enhance employees' affective commitment and normative commitment to the personified organisation. Institutional support should also increase affective commitment by fulfilling such socio-emotional needs as affiliation and emotional support (Eisenberger et al., 1986; Armeli et al., 1998). Such need fulfilment produces a strong sense of belonging to the organisation, involving the incorporation of employees' membership and role status into their social identity. Institutional support should strengthen employees' beliefs that the organisation recognises and rewards increased performance (i.e. performance-reward expectancies). These processes should have favourable outcomes both for employees (e.g. increased job satisfaction and heightened positive mood) and for the organisation (e.g. increased affective commitment and performance, reduced turnover). The relationship of institutional support to behavioural intentions to leave has been assessed (Guzzo, Noonan, \& Elron, 1994), as have actual withdrawal behaviours such as tardiness, absenteeism, and voluntary turnover. Retention of organisational membership, high attendance and punctuality provide publicly identifiable ways for employees to reciprocate institutional support. A key concept associated with institutional support is the norm of reciprocity (Gouldner, 1960). According to institutional support theory, there can be a positive impact on employee attitudes and behaviours mainly because it creates a sense of obligation within the individuals to repay the organisation (Eisenberger et al., 1986; Eisenberger, Fasolo, \& Davis-LaMastro, 1990). Malhotra and Mukherjee (2004) support this relationship and contend that employees who are supported are more likely to be committed to their jobs and produce 
quality service because of their willingness to contribute to the organisation's success. When employees perceive that they are supported, they tend to be committed to and identify with the organisation as well as help the organisation succeed through citizenship behaviour and decreased withdrawal behaviours (Rhoades \& Eisenberger, 2002). In a similar vein, Makanjee, Hartzer and Uys (2006) conducted research on radiographers and found a positive effect of institutional support on organisational commitment. Accordingly, the following hypothesis is formulated:

\section{H1: Institutional support is positively related to teacher job commitment.}

\subsection{Institutional support and teacher job satisfaction}

Supporting employees brings them pleasure and a sense of belonging in their jobs and this leads to job satisfaction (Bilgin \& Dimirer, 2012). As Baranik, et al. (2010) have shown, organisational support in the form of mentorship activities such as coaching, counselling, protection and challenging assignments positively influences job satisfaction. Rhoades and Eisenberger (2002) support the positive correlation between institutional support and job satisfaction by pointing out that pleasure at work leads employees to go beyond assigned responsibilities. For example, they assist others, protect the business from risks, become innovative, suggest constructive ideas and acquire skills that help the organisation. In studying the relationship between institutional support and job satisfaction in the Chinese context, Miao (2011) found a positive and significant association between the two variables. This suggests that supporting employees is imperative in order to enhance job satisfaction. Similarly, studies on institutional support in Pakistan education institutions have indicated that, in addressing job dissatisfaction, institutional support is one of the important factors. The authors further observed that low perceived institutional support was associated with low educator job satisfaction. In addition, Chiang and Hsieh (2012) studied Taiwanese hotels and found a strong positive relationship between institutional support and job satisfaction. Therefore, the following hypothesis was developed:

H2: High levels of institutional support are associated with high levels of teacher job satisfaction.

\subsection{Institutional support and teacher job performance}

Literature has demonstrated that the relationship between institutional support and job performance is positive (Riggle, Edmondson and Hansen, 2009; Noblet \& Rodwell, 2009; Amin, 2013; Yozgat et al., 2013; Taghipour \& Dejban, 2013). For example, a meta-analysis of the relationship between perceived institutional support and job outcomes by Riggle, Edmondson and Hansen (2009) underscored a positive correlation between institutional support and job performance. Similar relationships were also found in Amin's (2013) study of the impact of institutional support on Pakistani academic employees' performance. The study reported that institutional support for career development and supervisory support are predictors of performance. In the Australian context, Noblet and Rodwell (2009) found that support from supervisors and colleagues represent important resources for enhancing police officers' commitment to the job and hence their job performance. Supported employees feel obligated to reciprocate by working extra hard in order to ensure organisational success (Miao, 2011; Ng \& Feldman, 2013). Based on the foregoing discussion, the following hypothesis is advanced:

H3: Institutional support positively correlates with the intention of teachers to increase performance levels.

\subsection{Ethical considerations}

The researchers applied all ethical considerations in line with the requirements of the University. This includes upholding the participants' confidentiality, trust and integrity at all times (Creswell 2005, 201). There was also an obligation not to publish any information that would betray their trust, including information that would compromise their dignity, by not divulging any information that could compromise the respondents and their institutions. The researchers strove at all times to seek the necessary permission of respondents and re-assure them that their responses would not be used against them. The research was conducted with objectivity and minimal bias. The research data were tested for validity and reliability (Heiman 2001, 61; Field 2009, 11). The consent of participants was sought before proceeding with the process and participants were reminded of their inherent right to refuse to participate if they believed that their participation might be harmful or detrimental to their situation. The researchers complied with the terms and conditions of the research. A covering letter was attached to the questionnaires, informing respondents that their anonymity would be maintained and respected and that conclusions drawn would not identify any institution by name. Respondents were 
requested to provide their candid opinions to ensure the authenticity of this research.

\section{Research Design and Methodology}

The design of this study is quantitative, between groups and between subjects, manipulating quasi-independent variables by using different participants (Field 2009) who were assigned particular conditions or positions for which they inherently qualified, such as gender. The respondents indicated their responses on a structured questionnaire, allowing the researchers to determine whether various independent groups of respondents differed statistically significantly from one another with respect to the dependent variables, which in this research were the factors obtained from the analysis of the items in Section B of the questionnaire. The selected unit of analysis was the teachers in the Gauteng province of South Africa in colleges and universities.

\subsection{Sample and data collection}

The target population for the study was South African teachers in colleges and universities in the Gauteng Province. Students from the Vaal University of Technology were recruited as research assistants to distribute and collect the questionnaires. Of the total of 170 questionnaires distributed, 150 usable questionnaires were retrieved for the final data analysis, representing a response rate of 89 percent. To eliminate differences in response patterns due to different reference points, all respondents were prompted to answer the questionnaire with reference to institutional support, teacher job satisfaction, teacher job commitment and teacher job performance, guided by the research assistants.

\subsection{Measurement Instrument and Questionnaire Design}

Research scales were operationalised on the basis of previous work. Proper modifications were made in order to fit the current research context and purpose. 'Institutional support' and 'job satisfaction' used a five-item scale adapted from Chinomona (2012). For the construct of institutional commitment, the measurement items were adopted from Weng, McElroy, Morrow and Liu (2010). Finally, 'teacher job performance' was measured using six-item scales adapted from Chiang and Hsein (2011). All measurement items were measured on a 5-point Likert type scale that was anchored by $1=$ strongly disagree to $5=$ strongly agree to express the degree of agreement.

\subsection{Respondent Profile}

Table 1 presents the profile of the participants. The profile indicates that 56.7 percent of the participants were females and the remainder were males. The age profile shows that 23.5 percent of the respondents were less than or 30 years of age while the remainder were above 30 years of age. Also, 67.3 percent of the respondents held diplomas while the reminder was made up of those who did not hold diplomas.

\section{Data Analysis}

\subsection{Structural Equation Modelling Approach}

In order to statistically analyse the measurement and structural models, this study used Smart PLS software for the Structural Equation Modelling (SEM) technique (Ringle, Wende \& Will, 2005). In SEM, the measurement model refers to the linkages between the latent variables and their manifest variables and the structural model captures the hypothesised causal relationships among the research constructs (Chin \& Newsted, 1999). Unlike AMOS and LISREL, which are covariance-based approaches, Smart PLS is a regression-based technique that originates from path analysis. Smart PLS has emerged as a powerful approach for studying causal models involving multiple constructs with multiple indicators (Chinomona \& Surujal, 2012). Smart PLS - a component-based method, has an ability to model latent constructs that are uncontaminated by measurement error under conditions of non-normality. It has the ability to handle complex predictive models in small-to-medium sample sizes. Since the current study sample size is relatively small (150), Smart PLS was found more appropriate to the purpose of the current study. In this respect, a bootstrapping resampling method was used to test the statistical significance of the relationships. This procedure entailed generating 200 sub-samples of cases randomly selected, with replacement, from the original data. Below is Table 2, presenting evidence on the reliability and 
validity of the measurement model.

\subsection{Measurement Model}

To ensure convergent validity, the researcher checked whether items loaded on their respective (a priori) constructs with loadings greater than 0.6 , while discriminant validity was checked by ensuring that there were no significant interresearch variable cross-loadings (Chin, 1998). As can be seen (Table 2), all items have loadings greater than 0.6 (i.e. ranging from 0.634 to 0.966 ), with no cross-loadings greater than 0.867 , while t-statistics derived from bootstrapping (200 resamples) suggest all loadings are significant at a $p$ value of 0.001 . This confirms that all the measurement items converged well on their respective constructs and are, therefore, acceptable measures.

Table 2: Accuracy Analysis Statistics

\begin{tabular}{|c|c|c|c|c|c|c|c|c|}
\hline & $\begin{array}{l}\text { Research } \\
\text { Construct }\end{array}$ & $\begin{array}{l}\text { LV Index } \\
\text { Value }\end{array}$ & $\begin{array}{l}\text { R-Squared } \\
\text { Value }\end{array}$ & $\begin{array}{c}\text { Cronbach's } \alpha \\
\text { value }\end{array}$ & $\begin{array}{l}\text { C.R. } \\
\text { Value }\end{array}$ & $\begin{array}{c}\text { AVE } \\
\text { Value }\end{array}$ & Communality & $\begin{array}{c}\text { Factor } \\
\text { Loading }\end{array}$ \\
\hline \multirow{5}{*}{ os } & IS 1 & \multirow{5}{*}{4.300} & \multirow{5}{*}{0.000} & \multirow{5}{*}{0.938} & \multirow{5}{*}{0.824} & \multirow{5}{*}{0.581} & \multirow{5}{*}{0.581} & 0.717 \\
\hline & IS 2 & & & & & & & 0.799 \\
\hline & IS 3 & & & & & & & 0.801 \\
\hline & IS 4 & & & & & & & 0.790 \\
\hline & IS 5 & & & & & & & 0.697 \\
\hline \multirow{5}{*}{ TJS } & TJS1 & \multirow{5}{*}{4.469} & \multirow{5}{*}{0.402} & \multirow{5}{*}{0.893} & \multirow{5}{*}{0.867} & \multirow{5}{*}{0.653} & \multirow{5}{*}{0.653} & 0.783 \\
\hline & TJS2 & & & & & & & 0.793 \\
\hline & TJS3 & & & & & & & 0.830 \\
\hline & TJS4 & & & & & & & 0.825 \\
\hline & TJS5 & & & & & & & 0.808 \\
\hline \multirow{12}{*}{ TJP } & TJP1 & \multirow{6}{*}{4.203} & \multirow{6}{*}{0.526} & \multirow{6}{*}{0.881} & \multirow{6}{*}{0.845} & \multirow{6}{*}{0.562} & \multirow{6}{*}{0.562} & 0.775 \\
\hline & TJP2 & & & & & & & 0.771 \\
\hline & TJP3 & & & & & & & 0.764 \\
\hline & TJP4 & & & & & & & 0.804 \\
\hline & TJP5 & & & & & & & 0.736 \\
\hline & TJP6 & & & & & & & 0.634 \\
\hline & TJC1 & \multirow{6}{*}{4.100} & \multirow{6}{*}{0.511} & \multirow{6}{*}{0.991} & \multirow{6}{*}{0.903} & \multirow{6}{*}{0.666} & \multirow{6}{*}{0.666} & 0.900 \\
\hline & $\mathrm{TJC2}$ & & & & & & & 0.908 \\
\hline & TJC3 & & & & & & & 0.845 \\
\hline & TJC4 & & & & & & & 0.807 \\
\hline & TJC5 & & & & & & & 0.966 \\
\hline & TJC6 & & & & & & & 0.934 \\
\hline
\end{tabular}

Note: IS = Institutional Support; TJS = Teacher Job Satisfaction; TJP = Teacher Job Performance; TJC=Teacher Job Commitment

According to Chin (1998), Bryne (2001) and Blunch (2008), research variables should have an average variance extracted (AVE) of more than 0.5 and a composite reliability of more than 0.7 (convergent validity), and inter-construct correlations should be less than the square-root of the AVE (discriminant validity). As can be seen (Table 2), all constructs exceeded these criteria, with AVE and CR generally equal to or greater than 0.562 and 0.824 respectively. Furthermore, as indicated in Table 3, the square-root of the lowest AVE is 0.88 and is greater than the highest interconstruct correlation value (0.749). All in all, these results confirm the existence of the discriminant validity of the measurement used in this study.

Table 3: Correlations between Constructs

\begin{tabular}{|l|c|c|c|c|}
\hline \hline \multicolumn{1}{|c|}{ Research Constructs } & OS & TJS & TJP & OC \\
\hline Institutional Support (IS) & 1.000 & & & \\
\hline Teacher Job Satisfaction (TJS) & 0.634 & 1.000 & 1000 & \\
\hline
\end{tabular}




\begin{tabular}{|l|l|l|l|l|}
\hline Teacher Job Performance (TJP) & 0.527 & 0.720 & 0,825 & 1.000 \\
\hline Teacher Job Commitment (TJC) & 0.637 & 0.749 & 0,889 & 1.000 \\
\hline \hline
\end{tabular}

Note: IS = Institutional Support; TJS = Teacher Job Satisfaction; TJP = Teacher Job Performance; TJC = Teacher Job Commitment

\subsection{Path Model}

PLS also generates the path coefficients for the relationships modelled among the constructs. The significance of these coefficients was assessed using the bootstrap procedure (with 200 sub-samples) that provided the t-values for each path estimate. Table 4 presents the results of the PLS analysis on the structural model, along with the path estimates and tvalues. Support for the study hypotheses, which are labelled on their corresponding paths, could be ascertained by examining the directionality (positive or negative) of the path coefficients and the significance of the $t$-values. The standardised path coefficients are expected to be at least 0.2 and preferably greater than 0.3 (Chin, 1998). The results provide support for the proposed positive relationships between the three hypotheses $(\mathrm{H} 1, \mathrm{H} 2$, and $\mathrm{H} 3)$. However, results in Table 4, indicate that three hypotheses (i.e. $\mathrm{H} 1, \mathrm{H} 2$ and $\mathrm{H} 3$ ) of the posited relationships are statistically significant (i.e. T-statistics value is greater than 2). Table 4 provides the path coefficients for $\mathrm{H} 1, \mathrm{H} 2$ and $\mathrm{H} 3$ (i.e. $0.634,0.600$ and 0.645 respectively).

Table 4: Results of Structural Equation Model Analysis

\begin{tabular}{|l|c|c|c|c|}
\hline \hline \multicolumn{1}{|c|}{ Proposed Hypothesis Relationship } & Hypothesis & Path Coefficients & T-Statistics & Rejected / Supported \\
\hline Institutional Support (IS) $\rightarrow$ Teacher Job Satisfaction (TJS) & H1 & 0.634 & 15.449 & Supported \\
Institutional Support (IS) $\rightarrow$ Teacher Job Performance (TJP) & H2 & 0.600 & 13.186 & Supported \\
Institutional Support (IS) $\rightarrow$ Teacher Job Commitment & H3 & 0.645 & 16.281 & Supported \\
\hline \hline
\end{tabular}

Note: IS = Institutional Support; TJS = Teacher Job Satisfaction; TJP = Teacher Job Performance TJC=Teacher Job Commitment

Following formulae provided by Tenenhaus, Vinzi, Chatelin \& Lauro, (2005), the global goodness-of-fit (GoF) statistic for the research model was calculated using the equation:

$$
\mathrm{GoF}=\sqrt{\overline{\mathrm{AVE}} * \overline{\mathrm{R}^{2}}}
$$

The calculated global goodness of fit $(\mathrm{GoF})$ is 0.87 , which exceeds the threshold of $\mathrm{GoF}>0.50$ suggested by Wetzels, Odekerken-Schröder \& van Oppen (2009). Thus, this study concludes that the research model has a good overall fit.

\section{Discussion and Conclusion}

The purpose of this study was to investigate institutional support on teachers' job satisfaction, job commitment and performance. In particular, three hypotheses were postulated. To test the proposed hypotheses, data were collected from teachers in colleges and universities in Gauteng province. The empirical results supported all the three research hypotheses in a significant way.

What is important to note about the study findings is the fact that institutional support has stronger effects on teacher job satisfaction (0.634) than on teacher job performance $(0.600)$. However, institutional support influences teacher job commitment (0.645) more strongly than institutional support influences teacher job performance (0.600). By implication, this finding indicates that institutional support has a strong influence on teacher job commitment. Perhaps this could be due to the fact that the effects of institutional support are likely to be teacher satisfying, causing teachers to be committed to their jobs and ultimately the teachers are therefore motivated to perform better- which sounds logical

\subsection{Implications of the study}

The ever-increasing importance of institutional support to teachers in South Africa cannot be over-emphasised. In particular, institutional support has been used to enhance teacher job satisfaction and to improve their performance 
during this era of educational transformation. The current study is an attempt to undertake research in an often neglected but important sector of the South African economy. Therefore, the findings of this empirical study are expected to have important implications for both practitioners and academicians.

On the academic side, this study makes a significant contribution to the organisational literature by systematically exploring the impact of institutional support on job satisfaction, job commitment and performance of teachers. In particular, the current study findings provide tentative support for the proposition that organisational support should be recognised as a significant antecedent to teachers' job satisfaction and as a tool to motivate them to improve their performance.

On the practitioners' side, the important influential role of institutional support for South Africa's teachers is highlighted. This study therefore submits that organisational leadership should develop strategies to support teachers, especially in terms of resources that should be adequate for competitive advantage. When teachers perceive support from the organisation, they are likely to enjoy their job and, consequently, produce quality work. Furthermore, practitioners, for instance managers who want to improve teacher performance, ought to target institutional support interventions that are considered motivating for teachers.

\subsection{Limitations and Future Research}

Notwithstanding the contribution of this study, it has limitations which provide avenues for future research. First and most significantly, the present research is conducted from the teachers' perspective in colleges and universities in the Gauteng province. Perhaps if data collection is expanded to include other universities, the research findings might be more insightful. Future studies should therefore consider this recommended research direction. Secondly, the current study was limited to teachers in colleges and universities in South Africa's Gauteng Province. Subsequent research should contemplate replicating this study in other provinces of South Africa, or even other African countries, for comparison of results. There is also the issue of common method bias, such as the measuring of all the questionnaires on the 5-point Likert scale; to avoid this, other researchers might opt to do the same research using different point scales such as 7- or 8-point scales. All in all, these suggested future avenues of study stand to contribute immensely to new knowledge in the existing body of literature on organisational behaviour, a subject that tends to receive relatively little attention from researchers in Africa.

\section{References}

Abdullah, A., Bilau, AA, Eneghuma, W.I., Ajogbe, A.M. \& Ali, K.N. (2011). Evaluation of Job Satisfaction and Performance of Employees in Small and Medium Sized Construction Firms in Nigeria. $2^{\text {nd }}$ International Conference on Construction and Project Management, IPEDR 15, Malaysia.

Amin, S.S.S. (2013). The Impact of Organisational Support for Career Development and Supervisory Support on Employee Performance: An Empirical Study from Pakistani Academic Sector. European Journal of Business Management, 5(5), 194-207.

Arshadi. N. (2011). The relationships of perceived organisational support (POS) with organisational commitment, in-role performance, and turnover intention: Mediating role of felt obligation. Nasrin ArshadiaOrganisational support. Social and Behavioral Sciences, 30, 1103- 1108.

Baranik, L.E., Roling, E.A. \& Eby, L.T. (2010). Why does Mentoring Work? The Role of Perceived Organisational Support. Journal of Vocational Behaviour, 76, 366-373.

Banai, M. Reisel, W.D. \& Probst, K. (2004). A managerial and personal control model: Predictions of work alienation and organisational commitment in Hungary. Journal of International Management, 10, 375-392.

Blau, P.M. (1964). Exchange and Power in Social Life, New York: John Wiley \& Sons.

Blunch, N.J. (2008). Introduction to Structural Equation Modelling using SPSS and AMOS. New Delhi. Singapore

Bilgin, N. \& Demirer, H. (2012). The Examination of the Relationship among Organisational Support, Affective Commitment and Job Satisfaction of Hotel Employees. Procedia-Social and Behavioural Sciences, 51, 470-473.

Borgogni, L., Ruso, S.D., Petitta, L. \& Vecchione, M. (2010). Predicting Job Satisfaction and Job Performance in a Privatised Organisation. International Public Management Journal, 13(3), 275-296.

Bowling, N.A. (2010). Effects of Job Satisfaction and Consequences on Extra-Role Behaviours. Journal of Business Psychology, 25,119-130.

Byrne, B.M. (2001). Structural Equation Modeling with AMOS. Basic concepts, Applications and programming. Multivariate applications series. New Jersey. London.

Carmeli, A. (2005). The relationship between organisational culture and withdrawal intentions and behaviour. International Journal of Manpower, 26 (2). 177-195.

Carmon, A. F. Miller, A.N. Raile, A.N.W. \& Roers, M.M. (2010). Fusing family and firm: Employee perceptions of perceived homophily, 
organisational justice, organisational identification, and organisational commitment in family businesses. Family Business Strategy, (1), 210-223.

Cater, B. \& Zabkar, V. (2009). "Antecedents and Consequences of Commitment in Marketing Research Services: The Client's Perspective," Industrial Marketing Management, 38(7), 785-797.

Casper, W.J, Harris, C. Taylor-Bianco, A. \& Wayne, J.H. (2011). Work-family conflict, perceived supervisor support and organisational commitment among Brazilian professionals. Journal of Vocational Behavior, 79 (2011) 640-652.

Celep. C. \& Yilmazturk, O.E. (2012). The relationship among organisational trust, multidimensional organisational commitment and perceived organisational support in educational organisations. Procedia - Social and Behavioral Sciences, 46, 5763 - 5776.

Cheng, P. Y. Yang. J. T. Wan, C.S. \& Chud, M.C. (2013). Ethical contexts and employee job responses in the hotel industry: The roles of work values and perceived organisational support. International Journal of Hospitality Management, 34, 108- 115.

Chiang, C.F. \& Hsieh, T.S. (2012). The Impact of Perceived Organisational Support and Psychological Empowerment on Job Performance. The Mediating Effects of Organisational Citizenship Behaviour, 31,180-190.

Chin, W.W, \& Newsted, P.R. (1999). Structural Equation Modeling analysis with Small Samples Using Partial Least Squares. In Rick Hoyle (Ed.), Statistical Strategies for Small Sample Research, Sage Publications, pp. 307-341. Thousand Oaks, CA: Sage

Chinomona, R. (2012). The impact of organisational support on work spirituality, organisational citizenship behaviour and job performance: The case of Zimbabwe's small and medium enterprises (SME) sector. African Journal of Business Management, 6 (36), 10003-10014.

Chinomona, R \& Surujlal, J. (2012). The influence of student internship work experience on their self-improvement and professionalism in Sport Management. African Journal for Physical, Health Education, Recreation and Dance (AJPHERD), 18 (4/2), 885-899.

Cramm, J.M, Strating, M.M.H, \& Nieboer, A.P. (2013). A large-scale longitudinal study indicating the importance of perceived effectiveness, organisational and management support for innovative culture. Social Science \& Medicine, 83, 119-124.

Cloete, N. (2011). South Africa: Radical new plan for higher education. Special reports. Global edition. Issue 200. Available: http:www.universityworldnews.com/article.php?story=2011120222252975 Accessed: October 4, 2013

Cropanzano, R. \& Mitchell. M.S. (2005). Social Exchange Theory: An Interdisciplinary Review. Journal of Management, 31(6), 874-900.

Cooper-hakim, A. \& Viswesvaran, C. (2005). The construct of work commitment: Testing an integrative framework. Psychological Bulletin, 131, 20, 241-256.

Damanpour, F., \& Evan, W. M. (1984). Organisational innovation and performance: The problem of "organisational lag". Administrative Science Quarterly, 29(3), 392-409.

Demirer, H. \& Bilgina, N. (2012). The examination of the relationship among organisational support, affective commitment and job satisfaction of hotel employees. Procedia - Social and Behavioral Sciences, 51, 470 - 473.

Eisenberger, R. R. Huntington, S. H. \& Sowa, D. (1986). Perceived organisational support. Journal of Applied Psychology, 71, 500-507.

Eisenberger, R., Fasolo, P., \& Davis-LaMastro, V. (1990). Perceived organisational support and employee diligence, commitment, and innovation. Journal of Applied Psychology, 75, 51-59.

Emerson, R.M. (1972), "Exchange theory, Part I: A psychological basis for social exchange", 38-57, "Exchange theory, Part II: Exchange relations and networks", 58-87, in Sociological Theories in Progress, vol.2, edited by J. Berger, M. Zelditch Jr. and B. Anderson, Boston, MA: Houghton-Mifflin.

Ferris, D.L, Brown, D.J \& Heller, D. (2009). Organisational supports and organisational deviance: The mediating role of organisationbased self-esteem. Organisational Behaviour and Human Decision Processes, 108, 279-286.

Field. A. (2009). Discovering statistics using SPSS. $3^{\text {rd }}$ Edition. London: Sage

Flynn, F.J. (2003). How much should I give and how often? The effects of generosity and frequency of favor exchange on social status and productivity. Academy of Management Journal, 46, 539-553.

Foa, E. B., \& Foa, U. G. (1980). Resource theory: Interpersonal behavior as exchange. In K. Gergen, M. S. Greenberg, \& R. Willis (Eds.), Social exchange: Advances in theory and research (pp. 77-94). New York: Plenum Press.

GeyskenS, I. Steenkamp,J.B.E.M. Scheer, L.K. \& Kumar, N. (1996). "The Effects of Trust and Interdependence on Relationship Commitment: A Trans-Atlantic Study," International Journal of Research in Marketing, 13(4), 303-317.

Gouldner, A. W. (1960). The norm of reciprocity. American Sociological Review, 25, 161-178.

Guest, D. (1987). Human Resource Management and Industrial Relations. Journal of Management Studies, 24:503-521.

Guzzo, R. A., Noonan, K. A., \& Elron, E. (1994). Expatriate managers and the psychological contract. Journal of Applied Psychology, $79,617-626$

Grawe, S.J. Daugherty, P.J. \& Macelroy, J.C. (2012). External organisation commitment among organisational implants: The case of logistics service providers. Transportation Research Part E, 48,165-177.

Georgellis , Y. Lange, T. \& Tabvuma, V. (2012). The impact of life events on job satisfaction. Journal of Vocational Behaviour, 80, 464473.

Hartline, M.D., \& Ferrell, O.C. (1996). The management of customer-contact service employees: an empirical investigation. Journal of Marketing, 60, 52- 70 .

Heiman, G.W.( 2001). Understanding research methods and statistics: An integrated introduction For psychology. 2nd Edition. Boston: Houghton-Mifflin.

Homans, G.C. (1958), "Social behaviour as exchange", The American Journal of Sociology, 63(6), 597-606.

Homburg, C., W. D. Hoyer, and M. Fassnacht (2002). "Service Orientation of a Retailer's

Business Strategy: Dimensions, Antecedents, and Performance Outcomes," Journal of Marketing, 66(4), 86-101. 
Iverson, R.D. (1996). Employee acceptance of organisational change. The role of organisational commitment, International Journal of Human Resource Management, 7, 147-157.

Kacmar, K.M. Bachrach, D.G. Harris, K.H. \& Noble, D. (2012). Exploring the role of supervisor trust in the associations between multiple sources of relationship conflict and organisational citizenship behaviour, The Leadership Quarterly. 23, 43-54.

Kumar, N., Hibbard, J.D. \& Stern, L.W. (1994), "The nature and consequences of marketing channel intermediary commitment", Working Paper Series, Report 94-115, Cambridge, MA: Marketing Science Institute.

Jones, D.A.\& McIntosh, B.R.( 2010). Organisational and occupational commitment in relation to bridge employment and retirement intentions. Journal of Vocational Behaviour, 77, 290-303.

Lau, C. \& Woodman, R.C. (1995). Understanding Organisational Change: A schematic perspective. Academy of Management Journal, $38,537-554$

Lovemore, G. (1998). Employee Satisfaction, Customer Loyalty, and Financial Performance. An Empirical Examination of the Service Profit Chain in Retail Banking. Journal of Service Research, 1 (1), 18-31.

Luo, Y. (2002). Contract, Cooperation, and Performance in International Joint Ventures, Strategic Management Journal, 23, 903-919

Lu, H., Barriball, K.L., Zhang, X. \& While, A.E. (2012). Job Satisfaction among Hospital Nurses Revisited: A systematic Review. International Journal of Nursing Studies, 49, 1017-1038.

Malhotra, N.K. (2007). Marketing research: An applied orientation. $7^{\text {th }}$ ed. Upper Saddle River: Prentice hall.

Makanjee, C.R, Hartzer, Y.F. \& Uys, I.L. (2006). The effect of perceived organisational support on organisational commitment of diagnostic imaging radiographers. Radiography, 12, 118-126.

Markovits, Y., Davis, A.J., Fay, D. \& Dick, R. (2010). The Link Between Job Satisfaction and Organisational Commitment: Differences Between Public and Private Sector Employees. International Public Management Journal, 13(2), 197-196.

Meyer, J. P. \& Allen, N. J. (1990). The measurement and antecedents of affective, continuance and normative commitment to the organisation. Journal of Occupational Psychology, 63, 1-18.

Meyer, J.P. \& Allen, N.J. (1991). A three-component conceptualisation of organisational commitment. Human Resource Management Review, 1, 61-89.

Meyer, J. P. \& Allen, N. J. (1997). Commitment in the workplace. Thousand Oaks, CA: Sage

Meyer, J.P. \& Herscovitch, L. (2001). Commitment in the workplace: toward a general model. Human Resource Management Review, $11,299-326$.

Meyer, J.P. Stanley, D.J. Herscovitch, L. \& Topolnytsky, L. (2002). Affective, continuance, and normative commitment to the organisation: a meta-analysis of antecedents, correlates, and consequences. Journal of Vocational Behaviour. 61, 20-52.

Miao, R.T. (2011). Perceived Organisational Support, Job Satisfaction, Task Performance and Organisational Citizenship Behaviour in China. Institute of Behavioural and Applied Management, 1, 1-23.

Morrow, P. C. (2011). Managing organisational commitment: Insights from longitudinal research. Journal of Vocational Behaviour, 14, 18-35.

Morrow, P.C, Macelroy, J.C. \& Scheibe, K.V. (2012). Influencing organisational commitment through office redesign. Journal of Vocational Behaviour, 81, 99-111.

Mowday, R. T., Porter, L. W., \& Steers, R. M. (1979). The measurement of organisational commitment. Jouranal of Vocational Behavior, 14, 224-227.

Ng, T.W.H. Sorensen, K.L. \& Yim, F.H.K. (2009). Does the Job Satisfaction-Job Performance Relationship Vary Across Cultures? Journal of Cross-Cultural Psychology, 40(5), 761-796.

Ng, T.W.H. \& Feldman, D.C. (2013). Does longer job tenure help or hinder job performance. Journal of Vocational Behaviour, 83, 305314.

Noblet, A.J. \& Rodwell, J.J. (2009). Identifying the Predictors of Employees' Health Satisfaction in a Npm. 11(5), 663-683.

Nordin, N. (2011). The Influence of Emotional intelligence, Leadership Behaviour and Organisational Commitment on Organisational Readiness for Change in Higher Learning Institution. Procedia - Social and Behavioural Sciences, 29, 129-138.

Phelps, E \& Zoega, G. (2013). Corporatism and job satisfaction. Journal of Comparative Economics, 41, 35-47.

Pfeffer, J. (2005). Producing sustainable competitive advantage through the effective management of people. Academy of Management Executive, 19, 95-106.

Riggle, R.J., Edmondson, D.R. \& Hansen, J.D. (2009). A Meta-Analysis of the Relationship between Perceived Organisational Support and Job Outcomes: 20 Years of Research. Journal of Business Research, 62, 1027-1030.

Ringle, C. M., Wende, S., \& Will, A. (2005). SmartPLS 2.0 M3. Available at http:// www.smartpls.de

Rhoades, L. \& Eisenberger, R. (2002). Perceived Organisational Support: A Review of the Literature. Journal of Applied Psychology, 87(4), 698-714.

Rubin, R.S., Bommer, W.H. \& Bachrach, D.G. (2010). Operant leadership and employee citizenship: A question of trust? The Leadership Quarterly, 21, 400-408.

Ruyter, K. L. Moorman, J. \& Lemmink, J. (2001). "Antecedents of Commitment and Trust in Customer-Supplier Relationships in High Technology Markets," Industrial Marketing Management, 30(3), 271-286.

Silvestro, R., \& Cross, S. (2000). Applying the service profit chain in a retail environment: Challenging the "satisfaction mirror". International Journal of Service Industry Management, 11 (3), 244-268.

Somers, M.J. (1995). Organisational Commitment, Turnover and Absenteeism: An Examination of Direct and Interaction Effects. Journal of Organisational Behaviour, 16, 49-58. 
Taghipour, A., \& Dejban, R. (2013). Job Performance: Mediate mechanism of work motivation. Procedia-Social and Behavioural Sciences. 84, 1601-1605.

Way, S.A., Sturman, M.C. \& Raab, C. (2010). What Matters More: Contrasting the Effects of Job Satisfaction and Services Climate on Hotel Food and Beverage Managers' Job Performance. Cornell Hospitality Quarterly, 51(3), 379-397.

Weng, Q., McElroy, J.C., Morrow, P.C., \& Liu, R. (2010). The relationship between career growth and organisational commitment. Journal of Vocational Behavior, 77 (3), 391-400.

Wheelan, T.L., \& Hunger, J.D. (2006). Strategic management and business policy. Upper Saddle River (NJ): Pearson Prentice-Hall

Wetzels, M., Odekerken-Schröder, G., \& Van Oppen, C. (2009). Using PLS path modeling for assessing hierarchical construct models: guidelines and empirical illustration. Management Information Systems Quarterly, 33(1), 177-195.

Yamaguchi, I. (2013). A Japan-US cross-cultural study of relationships among team autonomy, organisational social capital, job satisfaction, and organisational commitment. International Journal of Intercultural Relations, 37, 58-71.

Yeh, C.M. (2013). Tourism involvement, work engagement and job satisfaction among frontline hotel employees. Annals of Tourism Research. 42, 214-239.

Yen, C.H. \& Teng, H.Y. (2012). The effect of centralisation on organisational citizenship behaviour and deviant workplace behaviour in the hospitality industry. Tourism Management Review, 3, 1-10.

Yoon, M. H. \& Suh, J. (2003). Organisational citizenship behaviours and service quality as external effectiveness of contact employees. Journal of Business Research, 56, 597-611.

Yoon, J. \& Lawler, E.J. (2005). The Relational Cohesion Model of Organisational Commitment", in Relational Perspectives in Organisational Studies: A Research Companion.

Yozgat, U, Yurtkoru, S \& Bilginoglu, E. (2013). Job stress and job performance among employees in public sector in Istanbul: Examining the moderating role of emotional intelligence. Procedia-Social and Behavioural Sciences, 75, 518-524.

Zacher, H. \& Winter, G. (2011). Eldercare demands, strain, and work engagement: The moderating role of perceived organisational support. Journal of Vocational Behavior, 79, 667-680.

Zagenczyk, T.J, Scott,K.D, Gibney,R. Murrell, A.J. \& Thatcher, J.B. (2010). Social influence and perceived organisational support: A social networks analysis. Organisational Behaviour and Human Decision Processes. Organisational behaviour and Human Decision Processes, 111, 127-138.

Zellars, K.L., Tepper, B.J. \& Duffy, M.K. (2002). Abusive supervision and subordinates' organisational citizenship behavior. Journal of Applied Psychology, 87, 1068-1076.

Zellars, K.L. \& Tepper, B.J. (2003). Beyond social exchange: new directions for organisational citizenship behavior theory and research. Research in Personnel and Human Resources Management, 22, 395-424. 
